E3S Web of Conferences 1, 10004 (2013)

DOI: $10.1051 / \mathrm{e} 3$ sconf/20130110004

(c) Owned by the authors, published by EDP Sciences, 2013

\title{
Antimony in the Contaminated Site of EI Triunfo, Baja California Sur, Mexico
}

\author{
A. J. Marmolejo-Rodríguez ${ }^{1}$, M. A. Sánchez-Martínez ${ }^{1}$, V. R. Magallanes Ordóñez ${ }^{1}$, A. Sánchez González ${ }^{1}$ and O.F. \\ Becerra-Rueda $^{1}$ \\ ${ }^{1}$ Departamento de Oceanología, Centro Interdisciplinario de Ciencias Marinas, Instituto Politécnico Nacional. Av, I.P. \\ N. s/n, Col Playa Palo de Sta. Rita, 23096 La Paz, B.C.S. MEXICO, amarmole@ipn.mx, \\ masm_quimica@yahoo.com.mx, vmagalla@ipn.mx, alsanchezg@ipn.mx,fernando_chem@hotmail.com
}

\begin{abstract}
Antimony has properties similar to arsenic with some of its compounds toxic to humans. Therefore it is necessary to control the wastes accumulated by anthropogenic activities, such as mining, where it is in tailings to be released to the environment. According to the Environment Protection Agency, the maximum value in sediments is $11.2 \mathrm{mg} \mathrm{Sb} \mathrm{kg}$ and the Earth's crust average is $0.2 \mathrm{mg} \mathrm{Sb} \mathrm{kg}^{-1}$. In this semiarid area, the drainage basin El Carrizal is impacted with wastes of an abandoned gold mine at the Mining District El Triunfo (MD - ET) which have tailings with $17,600 \mathrm{mg} \mathrm{kg}^{-1}$ of antimony. In the main dry river (arroyo), the Sb content is between 0.6 and $122 \mathrm{mg} \mathrm{kg}^{-1}$. This element is transported from the source throughout the fluvial basin to discharge into the Pacific Ocean. In the arroyo mouth we collected one sedimentary core and the sediment from dunes $\left(28.6-45.7\right.$ and $\left.6.43-7.74 \mathrm{mg} \mathrm{Sb} \mathrm{kg}^{-1}\right)$. This research concluded the antimony is enriched in this semiarid system, with Normalized Enrichment Factors severely enriched mainly in arroyo sediments close to the MD-ET
\end{abstract}

Key words: Antimony, gold mine, contamination, trace elements

\section{Introduction}

Antimony is a metalloid considered toxic to most organisms at elevated concentrations (Filella et al., 2007). It is a naturally occurring element that belongs to group 15 of the periodic table of the elements, along with $\mathrm{N}, \mathrm{P}$, $\mathrm{As}$, and $\mathrm{Bi}$. It is not an essential element in plants or animals. Its bioavailability and toxicological effects depend on its chemical form and oxidation state, with the trivalent compounds more toxic than the pentavalent compounds, similar to arsenic (WHO, 2006).

\section{Study Area}

The hydrographical basin El Carrizal is a fluvial coastal system influenced by wastes of an abandoned gold mine. It is located in Baja California Sur, Mexico, about $40 \mathrm{~km}$ from La Paz (Fig. 1). Small towns such as El Triunfo, and El Carrizal are in this hydrographical basin where their inhabitants are exposed to tailings and ash with high concentrations of Potential Toxic Elements (PTE) such as arsenic, mercury, lead, and zinc (Carrillo, 1996, Volke-
Sepúlveda et al., 2003; Marmolejo- Rodríguez et al., 2011).

\section{Materials and Methods}

The overbank tailings $(n=19)$, arroyo sediments $(n=26)$, cores $(n=34)$, and dunes $(n=6)$ were sampled from the study area to determine the major and trace element contents in these semiarid environments. For antimony determinations, the sediment was digested with acid using four acids $\left(\mathrm{HCl}, \mathrm{HNO}_{3}, \mathrm{HClO}_{4}\right.$, and $\left.\mathrm{HF}\right)$. For these digestions the determination was made with an ICP-MS. (Inductively coupled-plasma mass spectrometry) The results were higher than the detection limits $(>500 \mathrm{mg} \mathrm{Sb}$ $\mathrm{kg}^{-1}$ ) therefore, the samples where measured again with Neutron Activation Analysis (INAA). The methods were validated with certified reference materials (PACS-2 and MESS-3). The results of this validation can be seen in Figure 2.

\section{Results and Discussion}




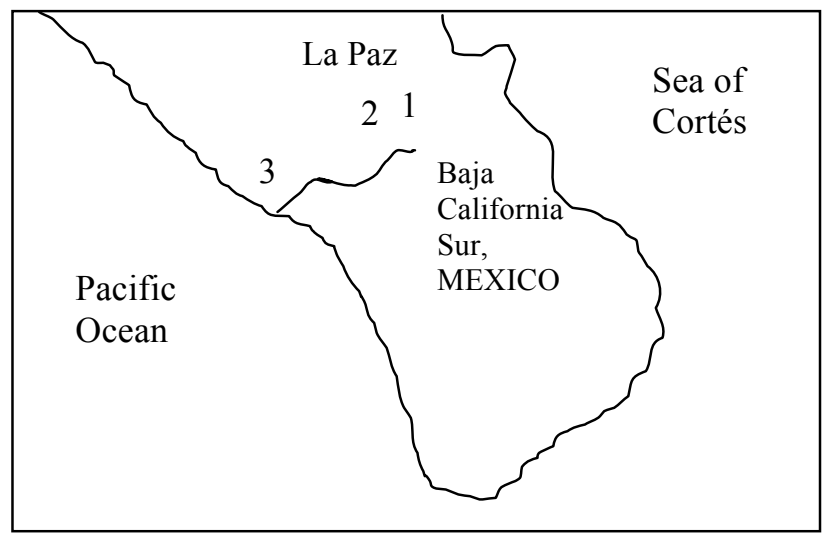

Fig. 1. Sampling site in the study area (1) El Triunfo town with abandoned gold mine overbank tailings, (2) Overbank tailings, and (3) Sediment core and dunes.

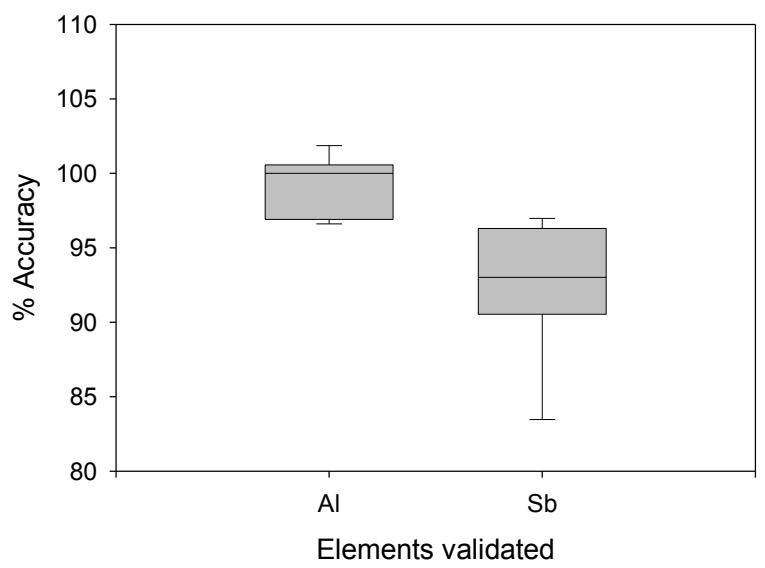

Fig. 2. Method validation with certified materials (PACS-2 and MESS-3). Accuracy corresponds to the certified material.

The grain-size analyses indicated that the sediment texture of the contaminated site is sand and silt-clay.

The results for the $\mathrm{Sb}$ in tailings, ash, arroyo, sediment core, and dunes are in Table 1.

The antimony concentrations in the different sampling sites studied here are compared with the Earth's Crust average (0.3 mg Sb kg-1 Wedepohl, 1995), and indicate that $\mathrm{Sb}$ is the severely enriched PTE in the study area. The results of $\mathrm{Sb}$ in tailings were extremely high and are in comparison with others determined in the vicinity of the study area (Volke-Sepúlveda et al., 2003; Posada-Ayala 2011). The validated results of the tailings in this study can be compared with those found in $\mathrm{Sb}$ mines (Wang et al., 2011; He et al., 2012; Hiller et al., 2012). The $\mathrm{Sb}$ in arroyo surface sediments decreases to the arroyo mouth at the Pacific Ocean, though the results show an accumulation in the core and dune sediments at the arroyo mouth.

The results of British soils (Flynn et al., 2003) show contents of $700 \mathrm{mg} \mathrm{kg}$ of $\mathrm{Sb}$ was found to be biologically unavailable over a wide range of $\mathrm{pH}$ values, indicating that $\mathrm{Sb}$ is relatively unreactive and immobile in the surface layers of the soil. This suggests that soil contamination by $\mathrm{Sb}$ caused by mining and smelting operations is not a severe risk to the environment or human health. This is good for the surface sediment results (Figure 3). However, the contents in the mining areas $>10,000 \mathrm{mg} \mathrm{Sb} \mathrm{kg}^{-1}$ (Table 1) suggest the mine wastes would have a great potential to contaminate the downstream environment.

Table 1. Results of $\mathrm{mg} \mathrm{Sb} \mathrm{kg}{ }^{-1}$ in tailings, ash, surface sediment, core sediment, and dunes in the hydrographic basin El Carrizal, B.C.S., Mexico.

\begin{tabular}{|c|c|}
\hline Matrix & $\begin{array}{l}\text { Range } \\
\left(\mathrm{mg} \mathrm{Sb} \mathrm{kg}^{-1}\right)\end{array}$ \\
\hline \multicolumn{2}{|l|}{ This study } \\
\hline Tailings overbank & $1.2-17,600$ \\
\hline Ash & $5,300-5,400$ \\
\hline Surface sediment & $0.6-122$ \\
\hline Core sediment & $28.6-45.7$ \\
\hline Dune sediments & $6.43-7.74$ \\
\hline \multicolumn{2}{|c|}{ Other studies in the same area } \\
\hline Soils $^{2}$ & $1.6-352$ \\
\hline Tailings $^{2}$ & $600-2063$ \\
\hline $\mathrm{Ash}^{2}$ & $2330-16,057$ \\
\hline Sediments $^{3}$ & $<0.1-18$ \\
\hline \multicolumn{2}{|c|}{ Other international studies } \\
\hline Soils of Great Britain ${ }^{4}$ & $11.89-709.84$ \\
\hline Soil in mining areas ${ }^{5}$ & $10.4-5045$ \\
\hline Background sediment $^{6}$ & 11.2 \\
\hline $\mathrm{Sb}$ mine sediment ${ }^{7}$ & $57-7316$ \\
\hline $\mathrm{Sb}$ mine sediment ${ }^{8}$ & 15,000 \\
\hline Earth Crust average $^{y}$ & 0.31 \\
\hline
\end{tabular}

${ }^{1}$ This study; ${ }^{2}$ Volke-Sepúlveda et al., 2003; ${ }^{3}$ PosadaAyala, 2011; ${ }^{4}$ Flynn et al., 2003; ${ }^{5} \mathrm{He}$ et al., 2012; ${ }^{6}$ Reimann et al., 2010; ${ }^{7}$ Wang et al.,2011; ${ }^{8}$ Hiller et al., 2012; ${ }^{9}$ Wedepohl, 1995.

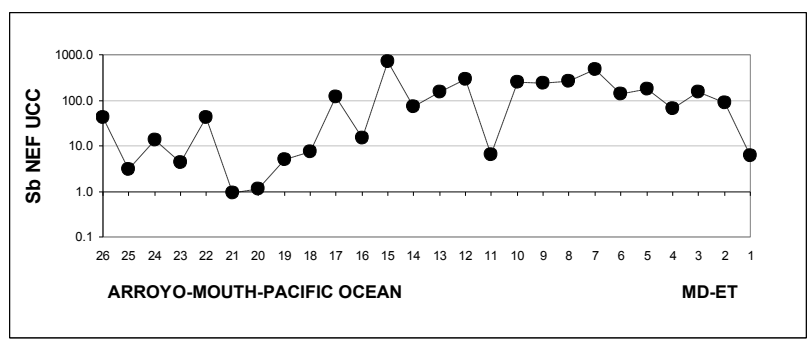

Fig. 3. Normalized Enrichment Factor (NEF) of Antimony in the surface sediment of the Arroyo HondoLas Gallinas-El Carrizal. NEF was calculated and compared with the Earth Crust (Wedepohl, 1995).

The abandoned mine wastes could contaminate water such as in Slovakia (Hiller et al., 2012), a similar scenario with the tailing wastes of this study area. Therefore, cleaner technologies must be developed and effectively 
implemented in the abandoned mining areas to avoid negative human health effects.

\section{Conclusion}

Our results indicate that exposure to tailings, ash, and sediments close to the MD-ET is potentially hazardous. Results from tailings are compared with antimony ore mines and their waste concentrations. It is necessary to remove the tailings or to extract most of the antimony contents in the tailings and ash to clean the zone. For the remediation of the fluvial system after removing the EPT, it is necessary to clean close to the abandoned installations of the inactive gold mine.

\section{Acknowledgements}

The authors thank the financial supports providing from: Secretaría de Investigación y Posgrado - Instituto Politécnico Nacional CICIMAR (Project SIP20110874 and 20120697).

\section{References}

Carrillo A. 1996. Environmental geochemistry of the San Antonio - El Triunfo mining area, southernmost Baja California Peninsula, Mexico. Ph D. Thesis in Geology, Laramie Wyoming, 130p.

Filella M., Philippo S., Belzile N., Chen Y., Quentel F. Natural attenuation processes applying to antimony: A study in the abandoned antimony mine in Goesdorf Luxemburg. Science of the Total Environment, 2009; 6205-6216.

Flynn H.C., Meharg A.A., Bowyer P.K., Paton G.I. Antimony bioavailability in mine soils. Environmental Pollution 2003; 124: 93-100.

He M., Wang X., Wu F., Fu Z. Antimony pollution in China. Science of the Total Environment 2012; 421422: 41-50.

Hiller E., Lalinska B., Chovan M., Jurkovic L., Kimbko T., Jankular M., Hovoric R., Sottnik P., Flakova R., Zenisova Z., Ondrejkova I. Arsenic and Antimony contamination of waters, stream sediments ad soils in the vicinity of abandoned antimony mines in the Western Carpathians Slovakia, Applied Geochemistry 2012; 27: 598-614.

Marmolejo- Rodríguez A.J., Sánchez-Martínez M.A., Romero-Guadarrama J.A., Sánchez- González A., Magallanes-Ordóñez V.R., Migration of As, $\mathrm{Hg}, \mathrm{Pb}$, and $\mathrm{Zn}$ in arroyo sediments from a semiarid coastal system influenced by the abandoned gold mining district at El Triunfo, Baja California Sur, Mexico Journal of Environmental Monitoring 2011; 13, 2182-2189.

Posada-Ayala I. H., Geoquímica ambiental del Distrito Minero San Antonio, sedimentos de los arroyos de la Cuenca de San Juan de los Planes y plataforma continental de Bahía La Ventana, B.C.S., México. 2011; Master Thesis 210pp. Volke-Sepúlveda T., Solórzano-Ochoa, G., Rosas Domínguez, A., Izumikawa C., Aguilar G.E., Velazco Trejo J.A., Flores-Martínez S., Remediación de sitios contaminados por metales provenientes de jales mineros en los distritos de El Triunfo- San Antonio y Santa Rosalía, Baja California Sur. Informe técnico. Dirección de Investigación en Residuos y proyectos regionales. Centro de Investigación y capacitación ambiental. Instituto Nacional de Ecología. 2003; 1-37.

Reimann C., Matschullat J., Birke M., Salminen R. Antimony in the environment: Lessons from geochemical mapping. Applied Geochemistry 2010; 25: 175-198.

Wang X., He M., Xi J., Lu X. Antimony distribution and mobility in rivers around the world's largest antimony mine of Xikuangshan Hunan Province, China. 2011; 97: 4-11. Wedepohl K.H. The composition of the continental crust. Geochemica et Cosmochimica Acta 1995; 59; 1217 - 1232.

WHO, Guidelines for drinking-water quality: Vol.ume 2. Health criteria and other supporting information. $2^{\text {nd }}$ ed. 1996. Geneva World Helath Organization; $2006 ; 937$. 